\title{
Vertebral compression fractures and mineral metabolism in chronic obstructive lung disease
}

\author{
J A RIANCHO, J GONZÁlEZ MACÍAS, C DEL ARCO, J A AMADO, J FREIJANES, \\ M A ANTÓN
}

From the Departments of Internal Medicine and Pharmacology, Hospital Nacional Marqués de Valdecilla, Facultad de Medicina, Santander, Spain

ABSTRACT Chronic obstructive lung disease has been reported as a cause of osteoporosis, thought whether this association is due to the disease itself or to corticosteroid treatment has not beers elucidated. We studied 44 male patients with chronic obstructive lung disease (mean (SD) FEV $39 \%$ $(14 \%)$ of predicted normal) who were not having long term corticosteroids. No differences in $\boldsymbol{w}_{\mathrm{p}}$ vertebral deformity score or in metacarpal index were found between them and a control group o\$ similar age. Indices of bone formation (serum osteocalcin) and bone resorption (urinary hydroxy proline) were normal and parathyroid hormone and 1,25-dihydroxyvitamin D were also normal $\stackrel{\mathbb{}}{-}$ Serum 25-hydroxyvitamin D was decreased, indicating depleted vitamin D. Calcitonin concentra $\vec{\emptyset}$ tions were higher in the patient than in the control group of the same age. There was no increase in the prevalence of osteoporosis in patients with chronic obstructive lung disease who had not received long term corticosteroid treatment. Increased concentrations of calcitonin may protect the skeletork from the detrimental effect of hypovitaminosis D.

Osteoporosis has been reported in patients with chronic obstructive lung disease, but this association is not well established. Most studies, however, have been performed in asthmatic patients rather than in patients with chronic obstructive bronchitis or emphysema, and have usually focused on the influence of corticosteroid administration, an accepted factor in the pathogenesis of osteoporosis. Other factors present in patients with chronic obstructive lung disease may be risk factors for osteoporosis. Important among them may be: low levels of physical activity, low sunlight exposure, a history of smoking, a history of alcohol consumption (which is known to be increased in chronic obstructive lung disease), and administration of calciuretic agents such as frusemide. ${ }^{1-4}$ Whether patients with chronic obstructive lung disease develop osteoporosis in the absence of steroid treatment is not known. Recent studies in asthmatic patients ${ }^{5}$ found a decreased bone mass only in patients treated with corticosteroids, contradicting some older reports. ${ }^{67}$

Address for reprint requests: Professor J González Macías, Departamento de Medicina Interna, Hospital Nacional Marqués de Valdecilla, 39008 Santander, Spain.

Accepted 3 August 1987
This study was undertaken to determine whether the prevalence of osteoporosis was increased in men witto chronic obstructive lung disease who had not had long term corticosteroid treatment and to study the activity of hormonal systems regulating bone metabolism i those patients.

\section{Methods}

SUBJECTS

A prospective study was performed from Decembet 1983 to September 1985. Entry criteria were a firna clinical and spirometric diagnosis of chronic obstruco tive lung disease and the ability to cooperate with the study. Patients with neoplasia, diabetes mellitus, livę disease (apart from liver congestion due to cof pulmonale), or impaired renal function were excludec By definition, patients with a history of chron corticosteroid treatment were also excluded. Chronis corticosteroid administration was defined as daily or alternate day administration for one year or more, of more than seven short courses of high dose treatment year. ${ }^{5}$

The study population consisted of 44 men (mea age 65 (SD 9) years). All suffered from symptoms \& 
their chronic obstructive lung disease, with an $\mathrm{FEV}_{\text {, }}$ of less than $80 \%$ of the prediced value. Mean (SD) respiratory function values (determined at rest) were: $\mathrm{FEV}_{1} 39 \%(14 \%)$, arterial oxygen tension $\left(\mathrm{PaO}_{2}\right)$ $62(11) \mathrm{mm} \mathrm{Hg}(8 \cdot 3(1.5) \mathrm{kPa})$, arterial carbon dioxide tension $\left(\mathrm{PaCO}_{2}\right) 47(8) \mathrm{mm} \mathrm{Hg}(6 \cdot 3(1 \cdot 1) \mathrm{kPa})$. Fourteen patients had a $\mathrm{PaO}_{2}$ below $60 \mathrm{~mm} \mathrm{Hg}(8 \mathrm{kPa})$, and $11 \mathrm{a} \mathrm{PaCO}_{2}$ higher than $50 \mathrm{~mm} \mathrm{Hg}(6.7 \mathrm{kPa})$.

Patients completed a questionnaire that included details of physical activity (average number of kilometres walked each week) and sunlight exposure (number of hours spent outdoors). Details of previous drug treatment and tobacco and alcohol consumption were also obtained. Most patients were taking some combination of theophylline, inhaled salbutamol, and inhaled ipratropium bromide. Seven of them had received short courses of corticosteroids during exacerbations (none more than three courses a year, each lasting no longer than three weeks).

All patients gave informed consent. The study was approved by the hospital research committee.

\section{SKELETAL RADIOGRAPHIC EVALUATION}

Lateral radiographs of the thoracic and lumbar spine were evaluated according to published criteria. ${ }^{8}$ The anterior, middle, and posterior heights of the vertebral bodies from T3 to L5 were measured. A score reflecting the degree of vertebral deformity due to wedging or compression fracture was determined as follows: (1) The whole spine was given one point. (2) One point was added for every vertebra with a $15-20 \%$ reduction in any of its heights, two points for a $21-$ $30 \%$ reduction, three for a $31-40 \%$ reduction, and four points when the reduction was greater than $40 \%$. Therefore an intact spine had a score of 1 , and the higher the score the worse the bone condition.

From radiographs of both hands the medullary width and total width were measured at the midpoint of the 2nd, 3rd, and 4th metacarpal of both hands, and the percentage ratio of cortical area to total area was calculated for each bone. ${ }^{9}$ The metacarpal index was taken as the average value of the six measured bones.

The patients' results were compared with those from a control group composed of 27 subjects of similar age (mean 60 (SD 9) years). All of them had diseases unrelated to bone metabolism, symptoms having been present for less than two months. None had been bedridden. All radiographs were evaluated by one of us (JAR) twice. He made the second reading after an interval of at least three months, being unaware of the score given in the first evaluation. The mean of both measurements was calculated.

BIOCHEMICAL EVALUATION

Thirty six of the 44 patients were studied biochemically. Blood samples were obtained for total and ionised calcium, phosphate, creatinine, parathyroid hormone, calcitonin, 25-hydroxyvitamin D $(25(\mathrm{OH}) \mathrm{D}), 1,25$-dihydroxyvitamin $\mathrm{D}\left(1,25(\mathrm{OH})_{2} \mathrm{D}\right)$, and osteocalcin (bone-Gla protein). Urine measurements included calcium, phosphate, creatinine, total hydroxyproline, and cyclic AMP (cAMP). Both blood and urine determinations were carried out on several occasions $(2-7$, mean $3 \cdot 1)$ during the study period.

Calcium, creatinine, and phosphate were analysed by standard automatic methods and ionised calcium by a Space-Stat 20 analyser (Orion Biomedical).

Parathyroid hormone was measured by radioimmunoassay (ImmunoNuclear) with a $\mathrm{C}$ terminal specific antibody. The normal range is up to $1 \mathrm{ng} / \mathrm{ml}$. Serum calcitonin and osteocalcin were also measured by radioimmunoassay (ImmunoNuclear), the normal ranges being up to $100 \mathrm{pg} / \mathrm{ml}$ and $1.8-6.6 \mathrm{ng} / \mathrm{ml}$ respectively. Vitamin D measurements included both $D_{2}$ and $D_{3}$ metabolites, and were performed by competitive protein binding assays, ${ }^{1011}$ after HPLC purification. The normal range for serum $1,25(\mathrm{OH})_{2} \mathrm{D}$ is $18-58 \mathrm{pg} / \mathrm{ml}(43-139 \mathrm{pmol} / \mathrm{l})$. In normal subjects serum $25(\mathrm{OH}) \mathrm{D}$ undergoes profound changes through the year, with a maximum in the late summer (30 (SD 10) $\mathrm{ng} / \mathrm{ml}, 75(25) \mathrm{nmol} / \mathrm{l})$ and a minimum in late winter (14 (6) $\mathrm{ng} / \mathrm{ml}, 35(15) \mathrm{nmol} / \mathrm{l})$.

Hydroxyproline and cAMP were measured in a morning two hour urine collection, after a 12 hour fast. Hydroxyproline was analysed by a colorimetric method (Organon Teknika) and the results expressed as the molar ratio to creatinine (normal range $0.005-$ $0.021 \mathrm{~mol}$ hydroxyproline/mol creatinine, $5.8-24.4 \mathrm{mg}$ hydroxyproline/g creatinine). cAMP was measured by radioimmunoassay (ImmunoNuclear) and the results were expressed as a function of the glomerular filtration rate (GFR) (normal range $1.85-5.0 \mathrm{nmol} / 100 \mathrm{mg}$ GFR).

\section{STATISTICAL ANALYSIS}

The results are expressed as means with standard deviations in parentheses unless otherwise specified. They were compared with those of control groups of similar age distribution. Owing to the difficulty of obtaining radiographs and blood and urine measurements in the same group, different control groups were used for different aspects of the study. The controls for the biochemical studies were all healthy subjects. Mann-Whitney U, Student's $t$, and $\chi^{2}$ tests and Pearson and Spearman correlation were applied as indicated. A probability of 0.05 was considered significant.

\section{Results}

SKELETAL RADIOGRAPHS

Two subjects in the control group $(7 \cdot 4 \%)$ and three in 


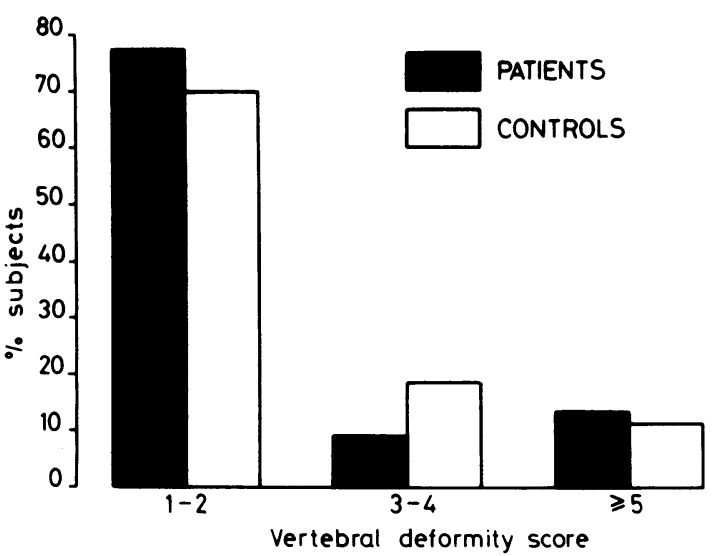

Fig 1 Frequency distribution of the vertebral deformity score in patients and in controls. Differences were not statistically significant.

the group with chronic obstructive lung disease $(5 \cdot 3 \%)$ had a grossly wedged vertebra (that is, more than $30 \%$ height lost). The mean vertebral deformity scores were $2.01(1.5)$ in the control group and $2.6(3.5)$ in the patients group, and were not significantly different. The metacarpal index was $72 \%(7 \%)$ in the control group and $73 \%(6 \%)$ in the group with chronic obstructive lung disease. No significant differences were observed in the frequency distributions (figs 1 and 2). Ninety five percent confidence intervals for differences between the two groups were: metacarpal index 0 to $+2 \cdot 4$; vertebral deformity score (percentage of subjects with a score higher than 4$)-13 \%$ to + $18 \%$.

No significant correlation between the severity of lung disease $\left(\mathrm{FEV}_{1}, \mathrm{PaO}_{2}\right.$, or $\left.\mathrm{PaCO}_{2}\right)$ and bone indices

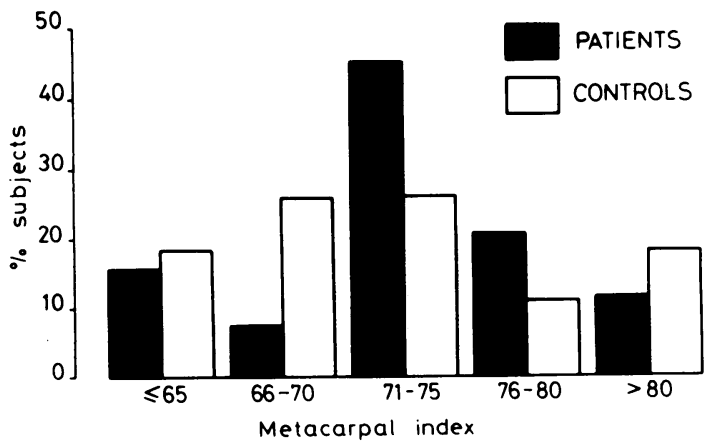

Fig 2 Frequency distribution of the metacarpal index in patients and in controls. Differences were not statistically significant.
Mean (SD) hormone concentrations and indices of bone $\overrightarrow{0}$ turnover in patients and control subjects

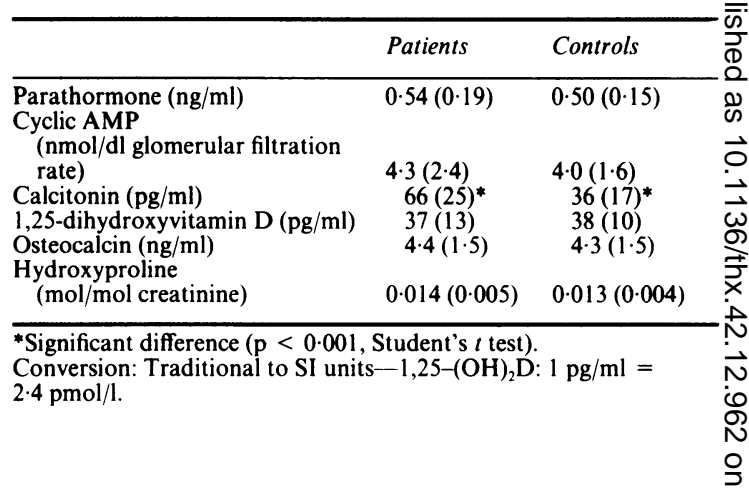

were observed. No relationship was observed between bone indices and tobacco consumption, alcohol consumption, or sunlight exposure. Patients with a尺ึ vertebral deformity score higher than 5 walked shorter distances than those with lower score $(6(4) v 16(10) \stackrel{\Phi}{\text { D }}$ $\mathrm{km} /$ week; $\mathrm{p}<0.005)$. Since no patient complained of $\overrightarrow{0}$ back pain, this finding indicates an influence of physical activity on bone.

\section{BIOCHEMICAL EVALUATION}

Serum total calcium $(8.8(0.5) \mathrm{mg} / \mathrm{dl}, 2.2(0.12)$ $\mathrm{mmol} / \mathrm{l})$; ionised calcium $(2.27(0.09) \mathrm{mEq} / \mathrm{l}, 1 \cdot 13$ ? $(0.04) \mathrm{mmol} / \mathrm{l})$; phosphate $(3.4(0.5) \mathrm{mg} / \mathrm{dl}, 1 \cdot 1(0 \cdot 1) \stackrel{\varrho}{\Omega}$ $\mathrm{mmol} / \mathrm{l})$; and TmP/GFR (3.0 (0.8) $\mathrm{mg} / \mathrm{dl}, 1.0(0.3)$ o $\mathrm{mmol} / \mathrm{l})$ were all within the normal range. Mean values of parathyroid hormone, $1,25(\mathrm{OH})_{2} \mathrm{D}$, osteocalcin, urinary cAMP, and hydroxyproline were also normal

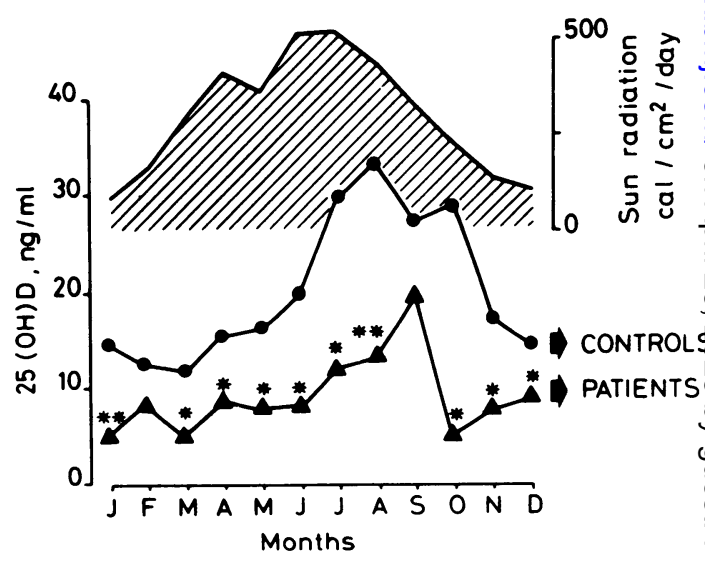

Fig 3 Serum concentrations of 25-hydroxyvitamin $D(25(O H) D)$ through the year. The relationship with sun radiation (expressed as mean daily calories $/ \mathrm{cm}^{2}$ ) is displayed ${ }^{*} p<0.02,{ }^{* *} p<0.001$. Conversion: Traditional to SI units-25(OH)D: $1 \mathrm{ng} / \mathrm{ml}=2.5 \mathrm{nmol} / \mathrm{l}$. 
(table). Serum calcitonin concentration was significantly higher than in a control group of the same age (table). The patients with chronic obstructive lung disease, however, showed a substantially lower serum $25(\mathrm{OH}) \mathrm{D}$ concentration (fig 3 ), $27 \%$ having less than $4.5 \mathrm{ng} / \mathrm{ml}$, the lowest value found among 132 healthy controls. A significant correlation $(r=0.66$, $\mathrm{p}<0.001$ ) existed between serum 25(OH)D and the number of hours spent outdoors in the previous two months.

No significant relationship was observed between any of the biochemical indices and radiographic bone indices. Likewise, patients with vitamin $\mathrm{D}$ deficiency (serum $25(\mathrm{OH}) \mathrm{D}$ below $4.5 \mathrm{ng} / \mathrm{ml}$ ) had bone indices not significantly different from patients with normal serum 25(OH)D.

\section{Discussion}

Chronic obstructive lung disease has been considered to be associated with an increased prevalence of osteoporosis, ${ }^{12}$ but few studies support this contention. Moreover, the influence of corticosteroid treatment may have been misleading in some of them. Earlier reports suggested an increased incidence of osteoporosis in asthmatic patients independent of corticosteroid treatment. ${ }^{67}$ Other investigations, however, have not supported this conclusion. ${ }^{5}$ We have studied a group of unselected men with chronic obstructive lung disease, suffering from chronic obstructive bronchitis or emphysema or both, who were not having chronic corticosteroid treatment. Thus the influence of steroid treatment was avoided in this study. Women were not included because of the much lower incidence of chronic obstructive lung disease in females, and because the menopause would introduce an additional variable in the interpretation of the results.

There was no greater prevalence of vertebral fractures in these patients than in a control group of men matched for age. The low prevalence of vertebral fractures could make it difficult to find differences between the two groups. Nevertheless, our results show that if any difference does exist it must be rather small and probably clinically insignificant. In accordance with that finding no relationship between bone indices and indicators of the severity of lung disease was observed. In addition, urine hydroxyproline and serum osteocalcin, markers for bone resorption and bone formation respectively, ${ }^{13}$ did not differ between patients and controls, suggesting that bone turnover was normal in the patients under study. Serum concentrations of parathyroid hormone and $1,25(\mathrm{OH})_{2} \mathrm{D}$, the main hormones regulating mineral metabolism, as well as other indices of parathyroid activity (TmP/GRF, urinary excretion of cAMP), were also normal. Serum calcitonin was significantly increased, in agreement with previous reports. ${ }^{14}$ This increase has been attributed to an increased synthesis by the Kultschitzky cells of the bronchial epithelium. ${ }^{15}$ An effect of medications, however, increasing cAMP concentrations in parafollicular cells of the thyroid, cannot be excluded. ${ }^{16}$

Serum concentrations of $25(\mathrm{OH}) \mathrm{D}$ were lower in patients than in controls, a significant proportion of them $(27 \%)$ having levels below the lower limit of normality. This finding was not explained by decreased concentrations of vitamin $D$ binding protein since the patients had neither protein loosing diseases nor liver insufficiency, and their serum concentrations of albumin were normal. A significant correlation was found between serum $25(\mathrm{OH}) \mathrm{D}$ and the time spent outdoors, suggesting that low exposure to sunlight was the reason for the reduced concentrations of $25(\mathrm{OH}) \mathrm{D}$. The hypovitaminosis $\mathrm{D}$ reflected by the low serum $25(\mathrm{OH}) \mathrm{D}$ concentration has been considered to favour the development of osteoporosis. ${ }^{17}$ Osteoporosis, however, was not more prevalent in patients than in controls, and no differences in bone indices were found between patients with normal and patients with reduced concentrations of $25(\mathrm{OH}) \mathrm{D}$. Since calcitonin is a physiological inhibitor of bone resorption, it is tempting to speculate that the increased concentrations of serum calcitonin found in these patients could have a protective role, preventing the loss of bone mass.

We found no evidence of an increased prevalence of osteoporosis in patients with chronic obstructive lung disease not having long term corticosteroid treatment, despite the existence of several risk factors for its development.

This work was supported in part by a grant from Caja de Ahorros de Santander y Cantabria.

\section{References}

1 Avioli LV. Osteoporosis: pathogenesis and therapy. In: Avioli LV, Krane SM, eds. Metabolic bone disease. Vol 1. New York: Academic Press, 1977:307-85.

2 Mazess RB, Whedon GD. Immobilization and bone. Calcif Tissue Int 1983;35:265-7.

3 Seeman E, Melton LJ, O'Fallon WM, Riggs BL. Risk factors for spinal osteoporosis in men. Am J Med 1983;75:977-83.

4 Fujita T, Chan JCM, Bartter FC. Effect of oral furosemide and salt loading on parathyroid function in normal subjects. Nephron 1984;38:109-14.

5 Adinoff AD, Hollister JR. Steroid-induced fractures and bone loss in patients with asthma. $N$ Engl $J$ Med 1983;209:265-8.

6 Stresemann E, Krokowski E. Der Mineralisationsgrad 
der Wirbelsäule nach landfristiger Corticosteroidbehanlung des chronischen Bronchialasthmas. Klin Wochenschr 1967;45:564-9.

7 Krokowski E, Stresemann E. Röntgenologische Bestimmungen des Mineralisationsgrades der Wirbelsäule von Kranken mit chronischem Bronchialasthma. Klin Wochenschr 1967;45:570-3.

8 Kleerekoper M, Parfitt AM, Ellis BI. Measurement of vertebral fracture rates in osteoporosis. In: Christiansen C, Arnaud CD, Nordin BEC, Parfitt AM, Peck WA, Riggs BL, eds. Proceedings of international symposium on osteoporosis. Copenhagen, 1984:103-9.

9 Nordin BEC. Osteoporosis with particular reference to the menopause. In: Avioli LV, ed. The osteoporotic syndrome: detection, prevention, and treatment. New York: Grune and Stratton, 1983:13-4.

10 Haddad JC, Chyu KJ. Competitive protein-binding radioassay for 25-dihydroxycholecalciferol. J Clin Endocrinol Metab 1971;33:992-6.

11 Reinhardt TA, Horst RL, Orf JW, Hollis BW. A microassay for 1,25-dihydroxyvitamin $\mathrm{D}$ not requiring high performance liquid chromatography: application to clinical studies. J Clin Endocrinol Metab 1984;58 91-4.

12 Goldring SR, Krane SM. Metabolic bone disease osteoporosis and osteomalacia. Disease a Mont 1981;27:1-103

13 Brown JP, Delmas PD, Malaval L, Edovard C, Chapu民̊ MC, Meunier PJ. Serum bone Gla-protein: a specifie marker for bone formation in postmenopausaL osteoporosis. Lancet 1984;1:1019-23.

14 Galan F, Hurtado J, Perez R, Garrido M. High plasm calcitonin concentrations in chronic bronchitis. $B \stackrel{\overrightarrow{2}}{\bar{C}}$ Med J 1982;285:850-1.

15 Becker KL, Nash D, Silva OL, Snider RH, Moore CFN Increased serum and urinary calcitonin levels in patients with pulmonary disease. Chest 1981;79:211-560

16 Vora NM, Williams GA, Hargis GK, et al. Comparativa effect of calcium and of the adrenergic system oP calcitonin secretion in man. $J$ Clin Endocrinol Metab. 1978;6:567-71.

17 Parfitt AM, Gallagher JC, Heaney RP, Johnson CCD Neer R, Whedon GD. Vitamin D and bone health if the elderly. Am J Nutr 1982;36:1014-31. 